Setsuo Furuta DDS,

Seichi T anigawa D DS PhD,

$\mathrm{H}$ iroshi O hmizo DDS,

H iroshi I wama M D

\title{
Increase of peak expira- tory flow by atropine is dependent on circadian rhythm
}

Purpose: To examine whether the bronchodilatory effect of atropine differs in the evening from the morning. M ethods: Thirteen adult healthy volunteers with no oral medication intake were studied. At 1600, peak expiratory flow (PEF) was measured three times, and the highest value recorded. Subsequently, the volunteer received $0.01 \mathrm{mg} \cdot \mathrm{kg}^{-1}$ atropine im, and the PEF was measured every $30 \mathrm{~min}$ for $180 \mathrm{~min}$. $0 \mathrm{n}$ a different day, at 0400 , the effect of atropine on the PEF was measured again in the same way.

Results: The PEF values before atropine at 1600 and 0400 were $485 \pm 92$ (350-730) and $458 \pm 76$ (340-600) $1 \mathrm{~min}^{-1},(\mathrm{P}<0.05)$. There was no difference in PEF values between the 1600 and 0400 time courses after atropine. The PEF value was increased only at $90 \mathrm{~min}$ at $1600(P=0.0012)$, but at 30,60, 90 and $120 \mathrm{~min}$ at $0400(P=0.0001)$.

Conclusion: Atropine administration has a weak bronchodilatory effect in the evening, but a stronger effect in the morning. Airways are narrower in the morning than in the evening, and this change is inhibited by atropine such that the PEF values are restored to those observed in the evening.

O bjectif : Vérifier si l'effet broncho-dilatateur de l'atropine est différent le matin et le soir.

Méthode : Treize volontaires adultes en bonne santé, qui ne prenaient pas de médicament par voie orale, ont participé à l'étude. À $16 \mathrm{~h}$, le débit expiratoire de pointe (DEP) a été mesuré trois fois et la valeur maximale, notée. Par la suite, les volontaires ont reçu $0,01 \mathrm{mg} \cdot \mathrm{kg}^{-1}$ d'atropine im et le DEP a été mesuré toutes les $30 \mathrm{~min}$ pendant $180 \mathrm{~min}$. Un autre jour, l'effet de l'atropine sur le DEP a encore été mesuré de la même manière à $4 \mathrm{~h}$ cette fois.

Résultats : Les valeurs du DEP avant l'administration d'atropine à $16 \mathrm{~h}$ et à $4 \mathrm{~h}$ ont été de $485 \pm 92$ (350-730) et de $458 \pm 76$ (340-600) I min-1', $(P<0,05)$. Après l'administration de l'atropine, il n'y avait pas de différence dans l'évolution temporelle des valeurs de DEP pour les groupes de $16 \mathrm{~h}$ et de $4 \mathrm{~h}$. Cependant, la valeur de DEP était augmentée à 90 min pour le groupe de $16 \mathrm{~h}(\mathrm{P}=0,0012)$, et à $30,60,90$ et 120 min pour l'expérimentation de $4 \mathrm{~h}(\mathrm{P}=0,0001)$.

Conclusion : L'administration d'atropine a un faible effet broncho-dilatateur en soirée, mais un effet plus important le matin. Les voies aériennes sont plus étroites le matin que le soir. Ce qui est inhibé par l'atropine. On retrouve ainsi, le matin, les valeurs du DEP observées en soirée.

From the D epartment of Anesthesiology, Central Aizu General H ospital, Aizuwakamatsu, Japan.

A ddress correspondence to: $\mathrm{H}$ iroshi I wama M D, D epartment of Anesthesiology, Central Aizu General H ospital, 1-1 Tsuruga-machi,

Aizuwakamatsu City 965-0011, J apan. Phone: 81-242-25-1515; Fax: 81-242-24-1529; E-mail: h-iwama@hakuyu.or.jp A ccepted for publication September 16, 2000. 
A NTICHOLINERGIC drugs, such as atropine, glycopyrrolate or scopolamine, are becoming less popular as premedicants. $\mathrm{N}$ evertheless, they are still used for their antisialogogue activity in patients undergoing intraoral or bronchoscopic examination. ${ }^{1}$ Although high doses of these drugs achieves considerable bronchodilatation, ${ }^{2}$ it is considered to be weak at the low doses used for premedication. Also, these drugs are unpopular because of the discomfort caused by thirst ${ }^{3,4}$ and the potential respiratory complications. ${ }^{5}$ Airway diameter exhibits a circadian rhythm, dilating in the evening and constricting in the morning. ${ }^{6,7}$ The leukotriene receptor antagonist as an asthmatic drug acts by inhibiting this circadian rhythm. ${ }^{8}$ Because the balance of the sympathetic-parasympathetic nervous systems also affect the tracheo-bronchial tone, ${ }^{9}$ anticholinergic drugs have also been used as an aerosol for the treatment of asthma. ${ }^{10}$ This autonomic nervous signals probably differ between the evening and morning. Therefore, even when the premedication dose of anticholinergic drugs are administered, the effects on bronchodilatory actions should be evaluated taking different times of day into consideration. U sing measurements of the peak expiratory flow (PEF) as a reflection of bronchodilation, ${ }^{11}$ we examined whether the bronchodilatory effects of the premedication dose of atropine differ between the evening and morning.

Patients and methods

After approval of the Institutional Committee, 13 adult healthy volunteers with no medication and oral intake for eight hours were enrolled into this study. Following instructions for standard PEF measurement using a portable peak flow meter (Personal Best ${ }^{\mathrm{TM}}, \mathrm{H}$ ealthscan Products, Cedar Grove, N J, U SA), PEF was measured three times in the upright position at 1600 on a specified day, and the highest value was recorded. Subsequently, the volunteer received $0.01 \mathrm{mg} \cdot \mathrm{kg}^{-1}$ atropine im into the right upper arm, and PEF was measured in the same way, every $30 \mathrm{~min}$ for $180 \mathrm{~min}$. The PEF values were obtained in a manner blind to the volunteers. At 0400 on a different day, PEF was measured before and after atropine using the same method.

The comparison of PEF value obtained before atropine at 1600 with that at 0400 was analyzed by paired $t$ test. The comparison of the time course of PEF values between both times was analyzed by repeated measure analysis of variance (ANOVA). Changes in PEF values either at 1600 or 0400 were analyzed by repeated measure one-way ANOVA, followed by Fisher's protected least significant difference for multiple comparisons, in which the value before atropine was compared with other values after atropine. $P<0.05$ was considered significant. $D$ ata are expressed as mean \pm SD (range) or number of patients.

\section{Results}

The age, weight and height of the volunteers was $25 \pm$ 3 (20-30) yr, $65 \pm 9$ (43-74) kg and $170 \pm 8$ (153-178) $\mathrm{cm}$, respectively. Eleven volunteers were male and two were female. The PEF values before atropine at 1600 and 0400 were $485 \pm 92(350-730)$ and $458 \pm 76$ $(340-600) 1 \cdot \mathrm{min}^{-1}$, respectively $(P<0.05)$. There was no difference between the time course of PEF values at 1600 and at $0400(P=0.4889)$. The PEF values increased only at $90 \mathrm{~min}$ after atropine at $1600(\mathrm{P}=$ $0.0012)$, but at $30,60,90$ and 120 min after atropine at $0400(P=0.0001)$ (Figure).

\section{Discussion}

Peak expiratory flow values reflect the diameter of the airway tract ${ }^{1}$. the PEF becomes greater as the airway becomes wider. Standard instruction for PEF measurement suggest that PEF is measured three times and the highest value is taken. Several portable peak flow meters are available for personal use and the measurement has been applied as a follow-up regimen of asthma or chronic obstructive pulmonary disease patients. ${ }^{8,10}$ Regarding circadian rhythm of airway, it has been reported to dilate most at 1600 and constrict at $0400,6,7$ so that the PEF was measured at these times in the present study.

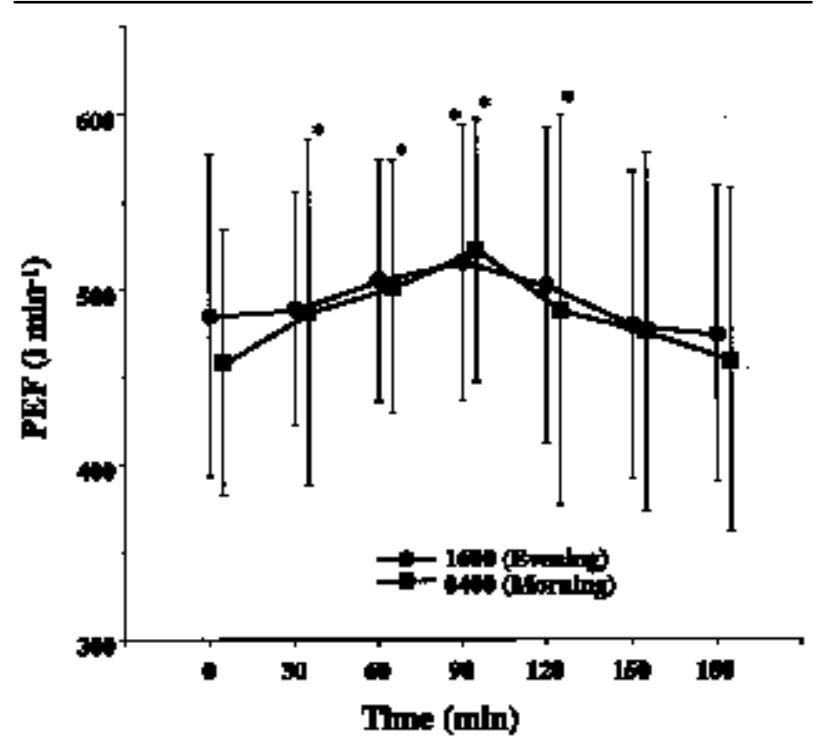

FIG U RE Time course of peak expiratory flow (PEF) after 0.01 $\mathrm{mg} \cdot \mathrm{kg}^{-1}$ atropine i $\mathrm{m}$ at 1600 (evening) or 0400 (morning). Values are mean $\pm S D$. $* P<0.05$ vs 0 -min value. 
Atropine im included in the premedication had a weak bronchodilator effect at 1600 , but a strong effect at 0400 . Airways narrowed from 1600 to 0400 , the change was inhibited by atropine and PEF values were restored to those obtained at 1600 . These results suggest that a low dose of atropine as used for premedication is able to change tracheo-bronchial tone within the physiological range by depressing the parasympathetic nervous signals. In the evening, since parasympathetic nervous signals were already depressed, the bronchodilatory effect would not be expected to be as great.

Atropine for premedication has been used to suppress saliva and tracheal mucus secretions and to prevent vaso- vagal reactions, but it is not commonly expected to have a bronchodilatory effect. In fact, some studies deny any bronchodilatory effect. ${ }^{4,12}$ Partly due to this, anticholinergic drugs such as atropine have been recently used via the iv route during anesthesia when vaso-vagal reactions occur. 0 therwise, these drugs are seldom used. From the present results, however, the bronchodilator effect of atropine would be expected in the morning and the duration of the effect would be approximately 120 min. Although the effect in the evening is small, it may still prevent bronchoconstriction or spasm of the airway tract caused by various stimuli. Thus, the use of anticholinergic drugs may be beneficial for anesthetic induction and maintenance. Particularly in patients with increased risk of airway hyper-reactivity and resultant bronchoconstriction, these drugs may prevent respiratory complications. As the im route is now not used for premedication, the drugs may be injected iv before anesthetic induction. The iv administration has a faster action than the im. In the morning, anticholinergic drugs alter the tracheo-bronchial tone resulting in bronchodilation within the physiological range. This concept, with reference to chronomedicine, may be called "chrono-premedication".

In conclusion, atropine im in a premedication dose had a weak bronchodilatory effect when given in the evening, but a stronger effect in the morning. Airways were narrower in the morning than in the evening, and this change was inhibited by atropine and the PEF values were restored to those obtained in the evening. These results suggest that the effect of anticholinergic drugs to produce bronchodilation is dependent on airway tract circadian rhythm.

\section{References}

1 Lichtor J L. Psychological preparation and preoperative medication In: M iller RD (Ed.). Anesthesia, 3rd ed. N ew York: Churchill Livingstone Inc., 1990: 895-928.
2 Dickstein J, Greenberg A, Kruger J, et al. $\mathrm{PCO}_{2}$ affects tracheal tone during apnea in anesthetized dogs. J Appl Physiol 1996; 81: 1184-9.

$3 \mathrm{~K}$ irvelä OA, K anto J H. Clinical and metabolic responses to different types of premedication. Anesth Analg 1991; 73: 49-53.

4 Williams T, Brooks T, Ward C. The role of atropine premedication in fiberoptic bronchoscopy using intravenous midazolam sedation. Chest 1998; 113: 1394-8.

5 J ones GC, D rummond GB. Effect of atropine premedication on respiratory complications. (Letter) $\mathrm{Br}$ J Anaesth 1981; 53: 441.

$6 \mathrm{H}$ etzel MR, Clark TJH . Comparison of normal and asthmatic circadian rhythm in peak expiratory flow rate. Thorax 1980; 35: 732-8.

7 Troyanov S, Ghezzo H, Cartier A, MaloJ-L. Comparison of circadian variations using $\mathrm{FEV}_{1}$ and peak expiratory flow rates among normal and asthmatic subjects. Thorax 1994; 49: 775-80.

8 Y okoyama A, K ohno N, Sakai K, H irasawa Y, K ondo K, $\mathrm{H}$ i wada $\mathrm{K}$. Effect of pranlukast, a leukotrience receptor antagonist, in patients with severe asthma refractory to corticosteroids. J Asthma 1998; 35: 57-62.

9 Barnes PJ. N eural control of human airways in health and disease. Am Rev Respir D is 1986; 134: 1289-314.

10 Levin DC, Little K S, Laughlin KR, et al. Addition of anticholinergic solution prolongs bronchodilator effect of beta 2 agonists in patients with chronic obstructive pulmonary disease. Am J M ed 1996; 100: 40S-8.

11 Vaughan TR, Weber R W, Tipton WR, N eson $\mathrm{HS}$. Comparison of PEFR and FEV in patients varying degrees of airway obstruction. Effect of modest altitude. Chest 1989; 95: 558-62.

12 Diaz JE, Dubin R, Gaeta TJ, Pelcar P, Bradley K. Efficacy of atropine sulfate in combination with albuterol in the treatment for acute asthma. Acad Emerg M ed 1997; 4: 107-13. 